OPEN ACCESS

Edited by:

Antonio Lupini,

Mediterranea University of Reggio

Calabria, Italy

Reviewed by:

Meriem Miyassa Aci,

Mediterranea University of Reggio

Calabria, Italy

Seyed Yahya Salehi-Lisar,

University of Tabriz, Iran

*Correspondence:

Tianming $\mathrm{Hu}$

hutianming@126.com

Xueqing $\mathrm{He}$

hexueqing@nwafu.edu.cn

Specialty section

This article was submitted to

Plant Nutrition,

a section of the journal

Frontiers in Plant Science

Received: 13 July 2021 Accepted: 06 September 2021

Published: 08 October 2021

Citation:

Song K, Gao J, Li S, Sun Y, Sun H,

An B, Hu T and He X (2021)

Experimental and Theoretical Study of the Effects of Rare Earth Elements on

Growth and Chlorophyll of Alfalfa

(Medicago sativa L.) Seedling.

Front. Plant Sci. 12:731838

doi: 10.3389/fpls.2021.731838

\section{Experimental and Theoretical Study of the Effects of Rare Earth Elements on Growth and Chlorophyll of Alfalfa (Medicago sativa L.) Seedling}

\author{
Kexiao Song, Jinzhu Gao, Shuo Li, Yunfu Sun, Haoyang Sun, Baiyu An, Tianming Hu* and \\ Xueqing $\mathrm{He}^{*}$
}

College of Grassland Agriculture, Northwest A\&F University, Yangling, China

Rare earth elements (REEs) of low concentration are usually beneficial to plant growth, while they are toxic at high concentrations. The effects of treatment with lanthanum (La) (10 and $20 \mu \mathrm{M})$, cerium (Ce) (10 and $20 \mu \mathrm{M})$, and terbium (Tb) (10 and $20 \mu \mathrm{M})$ on seedling growth of alfalfa (Medicago sativa L.), which is one of the most important perennial leguminous forages in the world, were studied. The results showed that all three REE treatments quickened the germination of seeds. The length of shoot under $\mathrm{La}(20 \mu \mathrm{M})$ treatment was significantly shortened $(P<0.05)$. In addition, treatment with $\mathrm{La}, \mathrm{Ce}$, and Tb had a "hormesis effect" on root length. There was a significant decrease in chlorophyll content on treatment with the three REEs, and the degree of decline was in the order of La $<\mathrm{Ce}<\mathrm{Tb}$, under the same concentration. In vitro experiments and quantum chemical calculations were further performed to explain why the treatments with REEs reduced the chlorophyll content. In vitro experiments showed that $\mathrm{La}, \mathrm{Ce}$, and Tb treatments reduced the absorbance of chlorophyll, and the decrease followed in the order of $\mathrm{La}>\mathrm{Ce}>\mathrm{Tb}$. Quantum chemical calculations predicted that the decrease in absorption intensity was caused by the reactions between $\mathrm{La}, \mathrm{Ce}, \mathrm{Tb}$, and chlorophyll, which formed lanthanideschlorophyll; and there were five types of stable lanthanides-chlorophyll. In conclusion, the decrease in chlorophyll content on treatment with REEs was caused by the change in chlorophyll structure.

Keywords: alfalfa, chlorophyll a, rare earth elements, quantum chemistry, lanthanides-chlorophyll

\section{INTRODUCTION}

Rare earth elements (REEs) are divided into two parts, light rare earth elements (LREE: cerium group elements) and heavy rare earth elements (HREE: yttrium group elements) (Binnemans et al., 2013), which are important plant growth stimulants in agriculture (Cotruvo, 2019; Kovaríková et al., 2019). Over the past decades, the application of REEs to plants has been investigated extensively (Chen, 2001; Hu et al., 2004; Lian et al., 2018; Yang et al., 2019; Fevzi et al., 2020). In 1980, when the field experiment started, China became the first country to use commercial rare earth fertilizers for crop production (Guo, 1985). 
Foliar spraying, seed treatment, fertilizer, and culture medium with REEs were carried out on a variety of crops, and the productivity of crops including wheat (Triticum aestivum) (Liang et al., 2005), soybean (Glycine max) (Cynthia et al., 2015), and other crops (Tommasi et al., 2020) increased by 5-15\% (Xiong et al., 2000). It was found that REEs had a "hormesis effect" on plant growth and development (d'Aquino et al., 2009; Wen et al., 2011; Ochi et al., 2014). The hormesis effect is a dose-response relationship phenomenon characterized by low-dose stimulation and high-dose inhibition. So, a suitable concentration of REEs could stimulate plant growth and development (Hong et al., 2017), and improve photosynthetic capacity (García-Jiménez et al., 2017) and crop quality (Ramírez-Olvera et al., 2018). In the laboratory, the positive effects of REEs on crop production and plant physiological responses have been reported extensively (Liu et al., 2012). An appropriate amount of REEs promotes seed germination and root development (Ma et al., 2010). REEs could enter the chloroplast through clathrin-mediated endocytosis (CME), which required extracellular arabinogalactan proteins (AGPs) that were anchored on the outer face of the plasma membrane (Wang et al., 2019). In comparison to LREEs, HREEs with $\mathrm{f}$ electrons were more likely to bind to AGPs (Yang et al., 2018), and Turra (2018) found that LREEs were more fluid than HREEs. La (III) and Ce (III) are LREEs without f electrons, which were found to have a "hormesis effect" on plants (d'Aquino et al., 2009), while Tb (III) is a typical representative of HREEs with $\mathrm{f}$ electrons. Different REEs may have different effects on plants (Wang L. H. et al., 2014), and therefore we selected two representative types of REEs (LREE: La and Ce; HREE: Tb) for a comparative study. Alfalfa (Medicago sativa L.) is a perennial herb of leguminous forage and is also known as the "king of forage." Alfalfa has the characteristics of long service life, high nutritional value, strong adaptability, and good economic and ecological benefits, so it is widely cultivated around the world (Krishna et al., 2020). Up to now, experiments with REEs on alfalfa have not been reported, and it is important to know how REEs affect the seedling growth of alfalfa.

Photosynthesis is an important aspect of the seedling growth of alfalfa. Photosynthesis is the physiological and material basis of plant growth (Xu et al., 2003), and it depends on chlorophyll. Chlorophyll contains a porphyrin ring, a central $\mathrm{Mg}$ ion, several sidechains, and a long hydrocarbon tail. There are two main types of chlorophyll, chlorophyll a and chlorophyll b. They differ only in the composition of the sidechain. The contents of chlorophyll $\mathrm{a}$ and chlorophyll $\mathrm{b}$ in wheat leaves increased with REEs (Chu, 1994). In rape (Brassica napus L.), the treatments with $\mathrm{CeCl}_{3}$ and $\mathrm{Nd}\left(\mathrm{NO}_{3}\right)_{3}$ increased the chlorophyll content by $9-40 \%$ (Jie and $\mathrm{Yu}, 1985)$. Our previous work showed that treatment with La increased the chlorophyll content of switchgrass (Panicum virgatum L.) (He et al., 2020). Shen et al. (1999) found that

\footnotetext{
Abbreviations: La, lanthanum; Ce, cerium; Tb, Terbium; REEs, rare earth elements; LREE, light rare earth elements; HREE, heavy rare earth elements; CME, clathrin-mediated endocytosis; AGPs, arabinogalactan proteins; FW, fresh weight; TTC, triphenyl tetrazolium chloride; MgCA, Mg-chlorophyll a; $\mathrm{MgCB}$, Mg-chlorophyll b; DFT, density functional theory; SDD, Stuttgart-Dresden; PCM, polarizable continuum model; SCRF, self-consistent reaction field; TDDFT, timedependent density functional theory.
}

$\mathrm{Nd}^{3+}$ replaced $\mathrm{Mg}^{2+}$ in the center of the chlorophyll porphyrin ring, but there was no detailed information about coordination. Hong et al. (2001) found that the content of rare earth element-binding chlorophyll accounted for about 1-6\% of the total chlorophyll in Osmunda foetida (Dicranopteris linearis), and speculated that $\mathrm{La}^{3+}, \mathrm{Ce}^{3+}$-chlorophyll was a double-layer structure, which was consistent with the experimental results in vitro (Hong et al., 2002). However, the most possible structure of lanthanides-chlorophyll and how the lanthanides-chlorophyll affects chlorophyll content of alfalfa are not clear yet.

Quantum chemical calculation is a powerful tool to explain the experimental phenomenon at the atomic level. It can predict the most stable structure and the most possible chemical reaction. It can also simulate the electronic absorption spectrum. With density functional theory (DFT), Liao et al. (2006) successfully predicted the molecular structures of lanthanide porphyrins. Otlyotov et al. (2020) optimized the molecular geometries of $\mathrm{Ca}$ and $\mathrm{Zn}$ complexes with porphyrazine. Yuriy et al. (2021) reported the molecular structures of Y, La, and Lu complexes with porphyrazine. Yin (2016) explored the possible reaction direction by calculating the Gibbs free energies of deprotonated and protonated species of porphyrin. With the time-dependent density functional theory (TD-DFT), Nemykin and Hadt (2010) simulated the electronic absorption spectra of ferrocenyl-containing porphyrins. Ziegler et al. (2013) calculated the electronic absorption spectra of $\mathrm{N}$-confused porphyrins. Both the values were consistent with the experimental UV-vis spectra. In the present work, we employed quantum chemical calculations and in vitro experiments to study the possible substitution reactions between chlorophyll and REEs ( $\mathrm{La}, \mathrm{Ce}$, and $\mathrm{Tb}$ ).

Therefore, in this study, the effects of two different concentrations of REEs ( $\mathrm{La}, \mathrm{Ce}$, and $\mathrm{Tb}$ ) on alfalfa seedlings were investigated in vivo. To get insight into the reason behind why $\mathrm{La}, \mathrm{Ce}$, and $\mathrm{Tb}$ treatments affect chlorophyll content, in vitro experiments and quantum chemical calculations were adopted to explore the possible reactions between chlorophyll and REEs (La, Ce, and $\mathrm{Tb}$ ). The purpose of this study was: (1) to reveal the effects of different REEs on alfalfa: seed germination, shoot length, root length, root activity, and chlorophyll content; (2) to predict the complex structures of REEs and chlorophyll, and explain the change in chlorophyll content based on the spectral property of the complexes.

\section{MATERIALS AND METHODS}

\section{Plant Material and Growth Conditions}

The mature seeds of alfalfa were purchased from Xi'an BeeLoo Landscape Design Co., Ltd. (China) in July 2020. They were then cleaned and stored in paper bags at room temperature for later use. According to the International Seed Testing Association (2017), the thousand-seed weight was $2.257 \mathrm{~g}$, and the seed viability was $97 \%$. Chlorophyll a and chlorophyll b mixture (BR) was purchased from Shanghai source leaf Biotechnology Co. Ltd. (China). $\mathrm{La}\left(\mathrm{NO}_{3}\right)_{3} \cdot 6 \mathrm{H}_{2} \mathrm{O}$ was purchased from Tianjin Guangfu Fine Chemical Research Institute (China), and its purity was more than $98 \%$. $\mathrm{Ce}\left(\mathrm{NO}_{3}\right)_{3} \cdot 6 \mathrm{H}_{2} \mathrm{O}$ was purchased from Afarsa (China) Chemical Co., Ltd. (China), and its purity was more than 
99.99\%. $\mathrm{Tb}\left(\mathrm{NO}_{3}\right)_{3} \cdot 6 \mathrm{H}_{2} \mathrm{O}$ was purchased from Macklin company (China), and its purity was more than $99 \%$.

\section{Germination Test}

The seeds of alfalfa were randomly selected and then pre-cooled at $4^{\circ} \mathrm{C}$ for $24 \mathrm{~h}$. After that, the seeds were disinfected with $75 \%$ alcohol for $30 \mathrm{~s}$ and washed five times with sterile water. There were seven treatments with $\mathrm{La}\left(\mathrm{NO}_{3}\right)_{3}(10 \mu \mathrm{M}, 20 \mu \mathrm{M})$, $\mathrm{Ce}\left(\mathrm{NO}_{3}\right)_{3}(10 \mu \mathrm{M}, 20 \mu \mathrm{M}), \mathrm{Tb}\left(\mathrm{NO}_{3}\right)_{3}(10 \mu \mathrm{M}, 20 \mu \mathrm{M})$, and $\mathrm{H}_{2} \mathrm{O}$. Moreover, there were three samples in each treatment, and there were 50 seeds in each sample. For each treatment, the seeds were germinated in petri dishes on a two-layer filter paper imbibed with $5 \mathrm{ml}$ of the corresponding solution, and then the seeds were put in a germination chamber at $25 \pm 2{ }^{\circ} \mathrm{C}, 85 \% \mathrm{RH}$, and a $16 / 8$ $\mathrm{h}$ photoperiod (light/dark) with 10000Lx irradiance for 14 days. They were replenished with a specific quantity of water every day. Germination was defined as the emergence of the radical through the coat.

Germination rate (\%)

$$
\begin{aligned}
= & \frac{\text { Number of germinated seeds after } \mathrm{n} \text { days }}{\text { Number of tested seeds }} \\
& \times 100 \%(n=4,14)
\end{aligned}
$$

\section{Seedling Growth Assay}

After 14 days of seed germination, the shoot length, and root length of all the seedlings were measured. Root activity was determined by the triphenyl tetrazolium chloride (TTC) method (Ejazul et al., 2007). TTC is a redox pigment. Its solution is colorless, but it produces a red compound on reduction. The red compound is relatively stable, and therefore, TTC is widely used as a hydrogen acceptor for enzyme tests. For testing root activity, fresh root tissues $(0.25 \mathrm{~g})$ were first immersed into $10 \mathrm{ml}$ phosphate buffer solution $(1 / 15 \mathrm{~mol} / \mathrm{L})$ containing $0.4 \%(\mathrm{w} / \mathrm{v})$ TTC and kept in the dark for $3 \mathrm{~h}$ at $37^{\circ} \mathrm{C}$. Next, $2 \mathrm{ml} \mathrm{H}_{2} \mathrm{SO}_{4}(1$ $\mathrm{mol} / \mathrm{L}$ ) was added. The roots were then dried and extracted with ethyl acetate. After that, the volume of red extract was increased to $5 \mathrm{ml}$ by adding ethyl acetate. Finally, the absorbance of the red extract was measured at $485 \mathrm{~nm}$. Root activity was calculated using the following equation:

Root activity $\left(\mathrm{mg} \cdot \mathrm{g}^{-1} \mathrm{~h}^{-1}\right)=\frac{\text { amount of TTC reduction }(\mu \mathrm{g})}{\text { fresh root weight }(\mathrm{g}) \times \text { time }(\mathrm{h})}$

To measure the chlorophyll content, a certain amount of fresh leaves was collected, and then they were ground for $60 \mathrm{~s}$. After that, they were soaked in $2 \mathrm{ml} 100 \%$ absolute ethanol for $24 \mathrm{~h}$ to extract chlorophyll. After centrifugation, the supernatant was adopted and its volume was increased to $7.5 \mathrm{ml}$ by adding absolute ethanol. Finally, the absorbances of supernatant were determined at wavelengths of $665 \mathrm{~nm}$ and $649 \mathrm{~nm}$. The values of chlorophyll content were expressed as $\mathrm{mg} / \mathrm{g}$ of fresh weight (FW).

$$
\begin{aligned}
\mathrm{Chl} \mathrm{a}(\mathrm{mg} / \mathrm{L}) & =13.70 \mathrm{~A}_{665}-5.76 \mathrm{~A}_{649} \\
\mathrm{Chl} \mathrm{b}(\mathrm{mg} / \mathrm{L}) & =25.80 \mathrm{~A}_{649}-7.60 \mathrm{~A}_{665} \\
\mathrm{Chl} \text { total }(\mathrm{mg} / \mathrm{L}) & =20.04 \mathrm{~A}_{649}+6.10 \mathrm{~A}_{665}
\end{aligned}
$$

Here, $\mathrm{A}_{665}$ and $\mathrm{A}_{649}$ are the absorbances of chlorophyll at 665 and $649 \mathrm{~nm}$, respectively (Rowan, 1989; Ritchie, 2006).

\section{In vitro Experiments}

The chlorophyll mixture [Mg-chlorophyll a (MgCA) and Mg-chlorophyll b (MgCB)] was dissolved in absolute ethanol, and then the absorbance was measured at $649 \mathrm{~nm}$ as a function of time within $120 \mathrm{~h} . \quad \mathrm{La}\left(\mathrm{NO}_{3}\right)_{3}(10 \mu \mathrm{M})$, $\mathrm{Ce}\left(\mathrm{NO}_{3}\right)_{3} \quad(20 \mu \mathrm{M}), \quad \mathrm{Tb}\left(\mathrm{NO}_{3}\right)_{3} \quad(20 \mu \mathrm{M}), \quad$ and absolute ethanol were separately mixed with $4 \mathrm{~mL}$ chlorophyll mixture solution in equal volume of 1:1. Ultravioletvisible spectra of these solutions and the absorbance were measured for $69 \mathrm{~h}$ using a spectrophotometer (Shimadzu UV-3900 UV-VIS Spectrophotometer, Tokyo, Japan). All the reactions concerning chlorophyll were conducted under dark conditions.

\section{Quantum Chemical Calculations}

All the calculations were performed by applying the Gaussian 09 software (Gaussian 09) (Frisch et al., 2010) with density functional theory (DFT). Geometric optimizations were carried out by B3LYP functional with empirical dispersion. The 6-31G(d) basis set was adopted for $\mathrm{C}, \mathrm{N}, \mathrm{O}, \mathrm{H}$, and $\mathrm{Mg}$, and the Stuttgart-Dresden (SDD) basis set was employed for $\mathrm{La}, \mathrm{Ce}$, and $\mathrm{Tb}$. The solvent effect was taken into account by the polarizable continuum model (PCM) of the self-consistent reaction field (SCRF) procedure in ethanol. The vibrational frequencies were computed to confirm that the optimized structures had no imaginary frequency. The Gibbs free energies were calculated for the optimized structures at $298.15 \mathrm{~K}$ and $101 \mathrm{kPa}$. Furthermore, the electronic absorption spectra of optimized structures were simulated using the TDDFT with the Coulomb attenuated method (CAM)-B3LYP functional.

\section{Statistical Analysis}

For statistical analysis, a one-way ANOVA was performed between treatment samples in three replications. To compare the seed germination rate, shoot length, root length, root activity, and total chlorophyll content of different treatments, data were analyzed using SPSS 26.0. The significant levels of difference for all the measured traits were calculated and means were compared by Duncan's multiple range test at a $5 \%$ level. Value of $P$ smaller than or equal to 0.05 was considered statistically significant.

\section{RESULTS}

\section{Plant Seedling Growth}

To reveal the effects of treatments with $\mathrm{La}, \mathrm{Ce}$, and $\mathrm{Tb}$ on alfalfa seedling, seed germination rate, root length, shoot length, root activity, and chlorophyll content were measured. The results showed that treatments with the three REEs with 10 and $20 \mu \mathrm{M}$ concentrations could speed up the germination of alfalfa, but had no significant effect on seed germination rate for the 14 days (Figures 1A,B).

As for shoot length, only $20 \mu \mathrm{M}$ La treatment had a significant difference with the control, and it reduced the shoot length by $3.66 \mathrm{~mm}$. For treatment with Ce, the increase in Ce concentration 

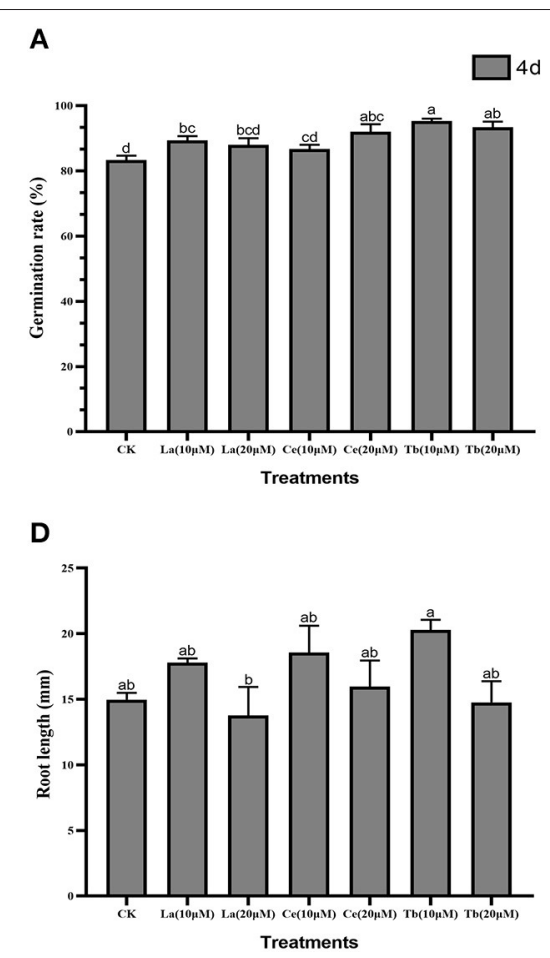

B

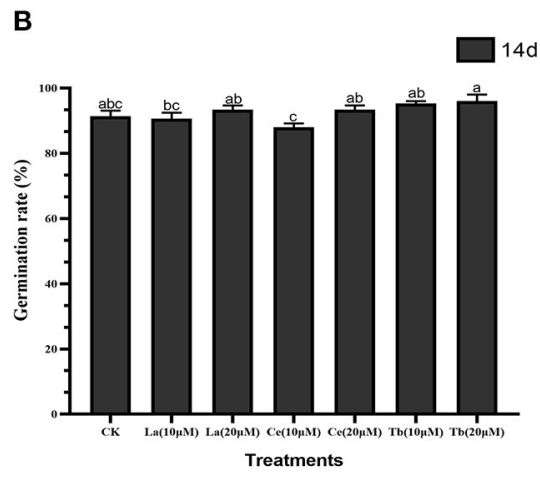

E

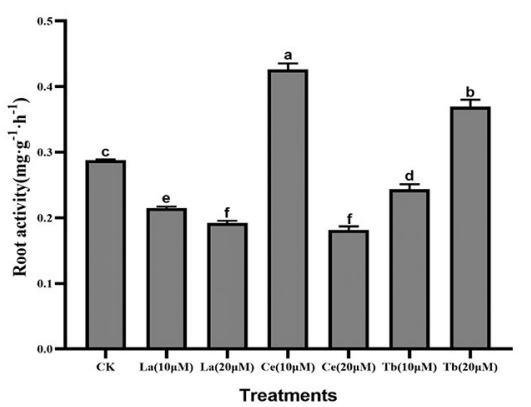

C

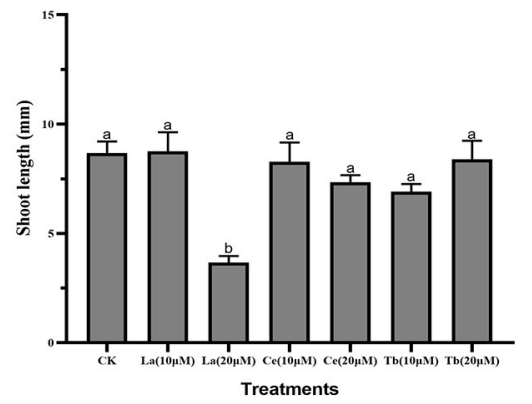

$\mathbf{F}$



FIGURE 1 | Effects of $\mathrm{La}, \mathrm{Ce}$, and Tb (10 and $20 \mu \mathrm{M})$ treatments on seed germination and seedling growth in Alfalfa. (A) Germination rate in 4 d, (B) germination rate in $14 \mathrm{~d}$, (C) shoot length, (D) root length, (E) root activity, (F) chlorophyll content. Means with different letters are significantly different at $p<0.05$.

from 10 to $20 \mu \mathrm{M}$ slightly shortened the shoot length, while treatment with $\mathrm{Tb}$ resulted in just the opposite (Figure 1C).

As for root length, the average root length of control was $14.98 \mathrm{~mm}$. Compared with the control, the treatment with $20 \mu \mathrm{M}$ La significantly reduced the root length, while the treatment with $10 \mu \mathrm{M} \mathrm{Tb}$ significantly elongated the root length. The average root lengths on treatments with $10 \mu \mathrm{M} \mathrm{La}, \mathrm{Ce}$, and Tb were 17.79, 18.56 , and $20.29 \mathrm{~mm}$, respectively, and the corresponding values were $13.77,15.97$, and $14.76 \mathrm{~mm}$ at the concentration of $20 \mu \mathrm{M}$. Compared with the control, all the treatments with $10 \mu \mathrm{M} \mathrm{La}$, $\mathrm{Ce}$, and $\mathrm{Tb}$ increased the root length, whereas all treatments with $20 \mu \mathrm{M} \mathrm{La}, \mathrm{Ce}$, and $\mathrm{Tb}$ decreased the root length, which showed the characteristic of "hormesis effect" (Figure 1D).

As for root activity, the value of the control was 0.286 $\mathrm{mg} /(\mathrm{g} \cdot \mathrm{h})$, and significant differences were found in all treatments. The two treatments with La significantly reduced the root activity of alfalfa. Compared to the control, the treatment with $10 \mu \mathrm{M}$ Ce significantly increased the root activity by $43.7 \%$, while the treatment with $20 \mu \mathrm{M}$ Ce significantly decreased the root activity by $35.4 \%$, which revealed the hormesis effect. On the contrary, the treatment with $10 \mu \mathrm{M}$ Tb significantly decreased the root activity by $20.6 \%$, whereas the treatment with $20 \mu \mathrm{M} \mathrm{Tb}$ significantly increased the root activity by $23.7 \%$ (Figure 1E).

Chlorophyll content was also an important index for aboveground growth. Compared with the control, all treatments with $\mathrm{La}, \mathrm{Ce}$, and $\mathrm{Tb}$ significantly decreased the chlorophyll content. The treatments with $10 \mu \mathrm{M} \mathrm{La}, \mathrm{Ce}$, and $\mathrm{Tb}$ decreased the chlorophyll content by $3.03,18.34$, and $24.33 \%$, respectively, and the corresponding values were 9.54, 15.71, and $24.86 \%$ under $20 \mu \mathrm{M}$ treatments. On the whole, the decrease in chlorophyll content was in the order of $\mathrm{La}<\mathrm{Ce}<\mathrm{Tb}$ (Figure 1F).

\section{In vitro Experiments}

The Absorbance of Chlorophyll Mixture as a Function of Time

To sum up, we found that all treatments with $\mathrm{La}, \mathrm{Ce}$, and $\mathrm{Tb}$ reduced the chlorophyll content in alfalfa leaves in vivo. We conducted in vitro experiments to reveal how the treatments with $\mathrm{La}, \mathrm{Ce}$, and $\mathrm{Tb}$ affected the chlorophyll content. Firstly, the absorbance of the purchased chlorophyll mixture [Mgchlorophyll a (MgCA) and Mg-chlorophyll b (MgCB)] in absolute ethanol was measured as a function of time. It can be seen in Figure 2 that the absorbance of chlorophyll mixture first increased from 0.112 to 0.124 within $60 \mathrm{~h}$, and then reached a plateau between 60 and $96 \mathrm{~h}$. Finally, it decreased after $96 \mathrm{~h}$. Our in vitro experiments of REE treatments were performed at the plateau.

\section{The Absorbance of Different Treatments in vitro}

The absorbance and UV-vis spectra of chlorophyll mixture $(\mathrm{MgCA}+\mathrm{MgCB})$ and three treatments $\left[\mathrm{La}\left(\mathrm{NO}_{3}\right)_{3}+\mathrm{MgCA}+\right.$ $\mathrm{MgCB}, \mathrm{Ce}\left(\mathrm{NO}_{3}\right)_{3}+\mathrm{MgCA}+\mathrm{MgCB}$, and $\mathrm{Tb}\left(\mathrm{NO}_{3}\right)_{3}+\mathrm{MgCA}$ $+\mathrm{MgCB}]$ were measured. The absorbance was measured at $649 \mathrm{~nm}$ as a function of time. In Figure 3A, it can be seen that all treatments with $\mathrm{La}, \mathrm{Ce}$, and $\mathrm{Tb}$ decreased the absorbance at $649 \mathrm{~nm}$, and the decrease was in the order of $\mathrm{La}>\mathrm{Ce}>\mathrm{Tb}$. 


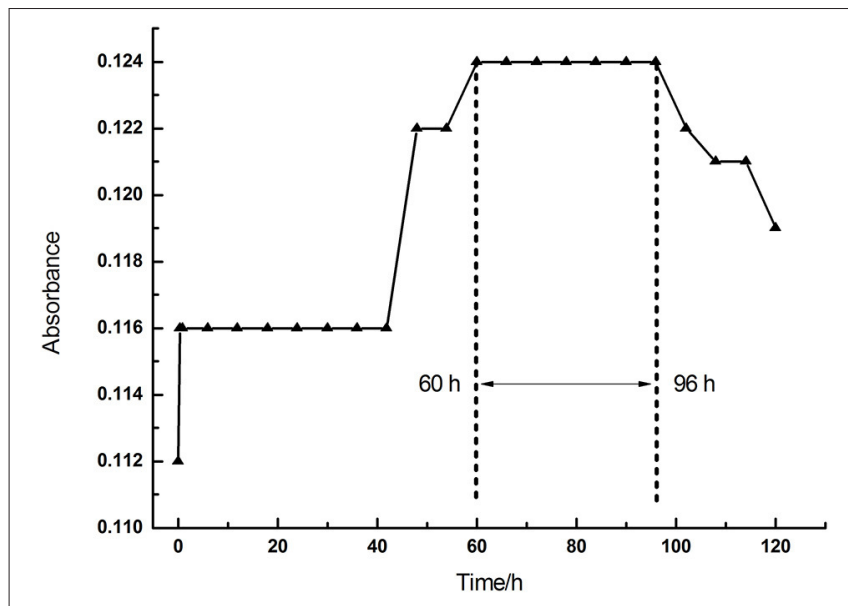

FIGURE 2 | The absorbance of chlorophyll mixture as a function of time (0-120 h).

In Figure 3B, the UV-vis spectra of chlorophyll mixture and treatments with $\mathrm{La}, \mathrm{Ce}$, and $\mathrm{Tb}$ were very similar, and the UVvis spectra had two strong absorption peaks in the visible region, which appeared at about 413 and $649 \mathrm{~nm}$, respectively. Moreover, at both absorption peaks, the absorbance of the chlorophyll mixture was always the largest.

\section{Quantum Chemical Calculations}

All the treatments with $\mathrm{La}, \mathrm{Ce}$, and $\mathrm{Tb}$ decreased the absorbance of the chlorophyll mixture in vitro, which was consistent with in vivo experiments. This situation indicated that $\mathrm{La}, \mathrm{Ce}$, and $\mathrm{Tb}$ might react with chlorophyll directly, and form lanthanides-chlorophyll. Under this circumstance, we further investigated the possible reactions between chlorophyll and $\mathrm{La}, \mathrm{Ce}$, and $\mathrm{Tb}$ with quantum chemical calculations.

In quantum chemical calculations, for the sake of simplicity, we only considered chlorophyll a. In the in vitro experiments, $\mathrm{La}, \mathrm{Ce}$, and $\mathrm{Tb}$ might replace $\mathrm{Mg}$ in chlorophyll a, and form lanthanides-chlorophyll. We systematically studied the possible products of reactions between chlorophyll a (MgCA) and $\mathrm{La}$, $\mathrm{Ce}$, and $\mathrm{Tb}$. We found that there were two kinds (lanthanides mono-chlorophyll a and lanthanides bis-chlorophyll a) and five possible compounds that were formed by REE and chlorophyll a, and we named them RECA1, RECA2, CARECA1, CARECA2, and CARECA3 $(\mathrm{RE}=\mathrm{La}, \mathrm{Ce}$, and $\mathrm{Tb})$. In RECA1, REE is coordinated with one porphyrin ring, and REE and the hydrocarbon tail are on different sides of the porphyrin ring. In RECA2, REE is coordinated with one porphyrin ring, and REE and the hydrocarbon tail are on the same side of the porphyrin ring. In CARECA1, REE is sandwiched by two porphyrin rings, and two long hydrocarbon tails are both on the outside. In CARECA2, REE is sandwiched by two porphyrin rings, and one long hydrocarbon tail is on the outside and the other is on the inside. In CARECA3, REE is sandwiched by two porphyrin rings, and both the long
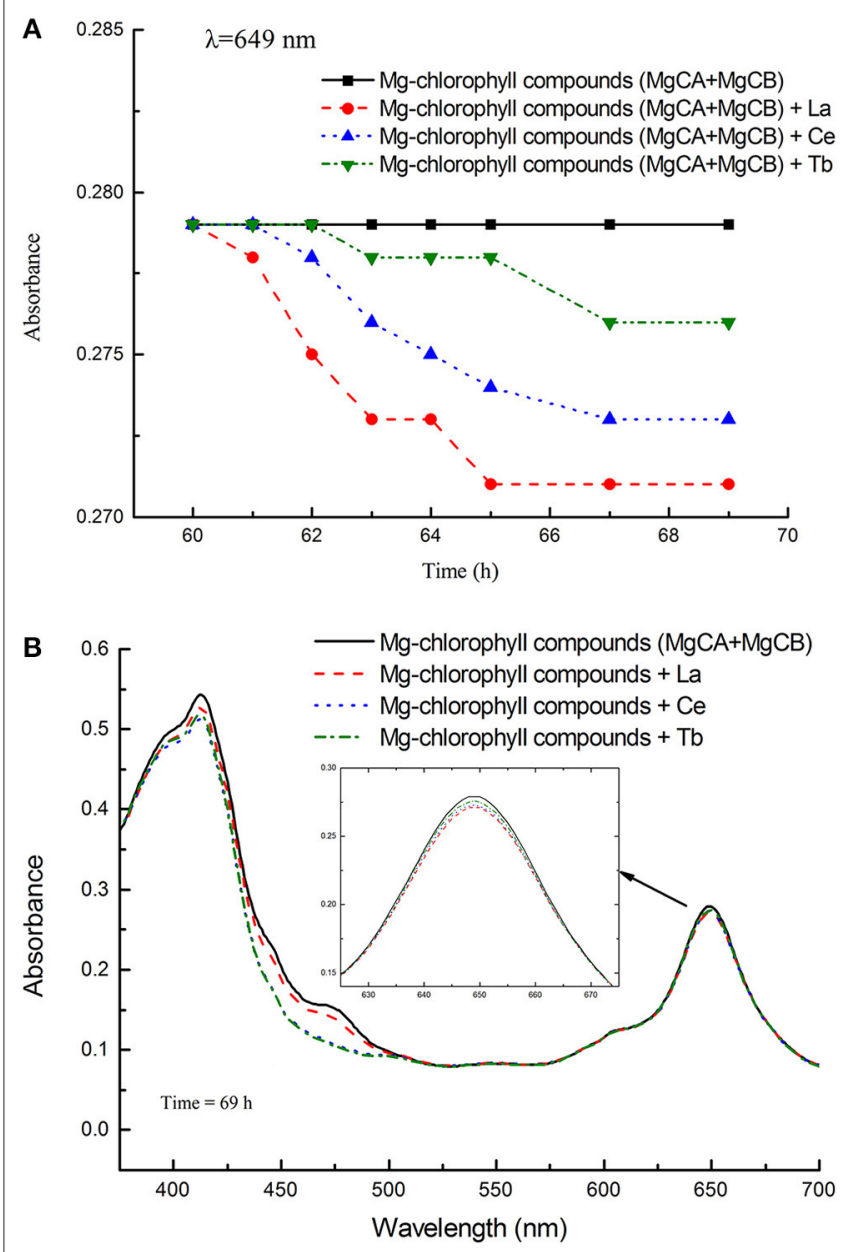

FIGURE 3 | The absorbance of different treatments in the in vitro experiments. (A) The absorbance of the blank control (MgCA + MgCB), $\mathrm{La}\left(\mathrm{NO}_{3}\right)_{3}+\mathrm{MgCA}$ $+\mathrm{MgCB}, \mathrm{Ce}\left(\mathrm{NO}_{3}\right)_{3}+\mathrm{MgCA}+\mathrm{MgCB}$, and $\mathrm{Tb}\left(\mathrm{NO}_{3}\right)_{3}+\mathrm{MgCA}+\mathrm{MgCB}$ treatments as a function of reaction time, (B) UV-vis spectra of the control $(\mathrm{MgCA}+\mathrm{MgCB}), \mathrm{La}\left(\mathrm{NO}_{3}\right)_{3}+\mathrm{MgCA}+\mathrm{MgCB}, \mathrm{Ce}\left(\mathrm{NO}_{3}\right)_{3}+\mathrm{MgCA}+\mathrm{MgCB}$, and $\mathrm{Tb}\left(\mathrm{NO}_{3}\right)_{3}+\mathrm{MgCA}+\mathrm{MgCB}$ treatments.

hydrocarbon tails are on the inside. The optimized structure is shown in Figure 4.

For these optimized structures, it was necessary to evaluate which compound was more stable and whether the given chemical reaction was thermodynamically possible. Therefore, the Gibbs free energies of these optimized structures at $298.15 \mathrm{~K}$ and $101 \mathrm{kPa}$ in ethanol were calculated, and these are listed in Table 1. Furthermore, the changes in Gibbs free energy for the chemical reactions between different compounds were also calculated. There are 15 chemical reactions between chlorophyll a and REEs ( $\mathrm{La}, \mathrm{Ce}$, and $\mathrm{Tb}$ ), and the changes in the Gibbs free energy for these reactions are illustrated in Figure 5.

Gibbs free energy is a thermodynamic function introduced to determine the direction of the chemical reaction. The smaller the change in Gibbs free energy, the greater the possibility for the reaction to occur. From Figure 5, it was seen that all the 


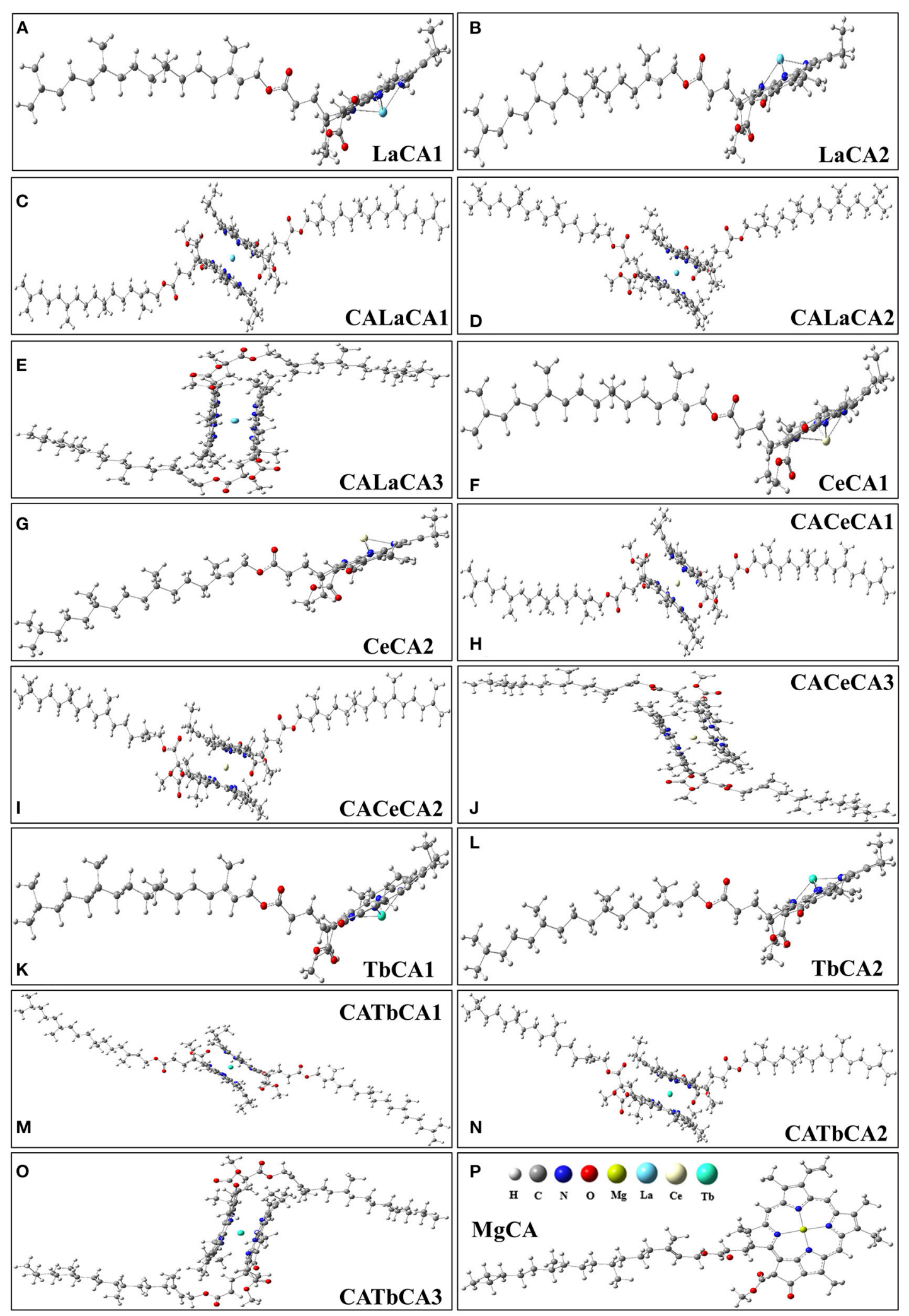

FIGURE 4 | Optimized structures of products for the reactions between La, Ce, Tb, and chlorophyll a. (A,B) lanthanum mono-chlorophyll a, (C-E) lanthanum bis-chlorophyll a, (F,G) cerium mono-chlorophyll a, (H-J) cerium bis-chlorophyll a, (K,L) terbium mono-chlorophyll a, (M-O) terbium bis-chlorophyll a, (P) chlorophyll a. 
TABLE 1 | Gibbs free energies of optimized structures.

\begin{tabular}{|c|c|c|}
\hline Compounds & & Gibbs free energy $\left(\mathrm{kJ} \cdot \mathrm{mol}^{-1}\right)$ \\
\hline 1 & $\mathrm{Mg}^{2+}$ & -524714.6869 \\
\hline 2 & $\mathrm{La}^{3+}$ & -1143186.1205 \\
\hline 3 & $\mathrm{Ce}^{3+}$ & -1246719.1896 \\
\hline 4 & $\mathrm{~Tb}^{3+}$ & -95035.9140 \\
\hline 5 & MgCA & -7702602.4755 \\
\hline 6 & LaCA1 & -8320793.2642 \\
\hline 7 & LaCA2 & -8320794.7029 \\
\hline 8 & CALaCA1 & -15498268.5368 \\
\hline 9 & CALaCA2 & -15498273.7615 \\
\hline 10 & CALaCA3 & -15498311.1198 \\
\hline 11 & CeCA1 & -8424410.7746 \\
\hline 12 & CeCA2 & -8424410.5645 \\
\hline 13 & CACeCA1 & -15601913.0951 \\
\hline 14 & CACeCA2 & -15601921.1490 \\
\hline 15 & CACeCA3 & -15601974.2000 \\
\hline 16 & TbCA1 & -7272777.8590 \\
\hline 17 & TbCA2 & -7272769.9717 \\
\hline 18 & CATbCA1 & -14450307.7417 \\
\hline 19 & CATbCA2 & -14450344.8920 \\
\hline 20 & CATbCA3 & -14450375.2118 \\
\hline
\end{tabular}

changes in Gibbs free energy were positive, and their values were in the range of $145-693 \mathrm{~kJ} \cdot \mathrm{mol}^{-1}$. Generally speaking, for the same REE, the Gibbs free energy changes for MgCA + REE reactions were much smaller than those for $2 \mathrm{MgCA}$ $+\mathrm{REE}$ reactions. As a result, lanthanides mono-chlorophyll a compounds were much easier to be formed than lanthanides bis-chlorophyll a compounds. For different REEs, the Gibbs free energy change for the same substitution reaction was different, and its value decreased in the order of $\mathrm{La}>\mathrm{Ce}>\mathrm{Tb}$, which indicated that it was easiest for $\mathrm{Tb}$ to form lanthanideschlorophyll a compounds. Moreover, for different REEs, the most stable lanthanides-chlorophyll a compound was also different. The most stable compounds for $\mathrm{La}, \mathrm{Ce}$, and $\mathrm{Tb}$ were $\mathrm{LaCA} 2$, CeCA1, and TbCA1, respectively.

\section{Electronic Absorption Spectrum}

Electronic absorption spectra of possible lanthanides-chlorophyll a compounds were simulated to reveal how the chlorophyll structure affected the absorbance.

As shown in Figures 6A-C, the electronic absorption spectrum of MgCA had two absorption peaks at 358 and $584 \mathrm{~nm}$, respectively. Compared to our UV-vis spectrum, these two peaks were blue-shifted by 53 and $65 \mathrm{~nm}$, respectively. Indeed, our electronic absorption spectrum of MgCA was consistent with the previous calculations (Chen et al., 2003; He et al., 2020).

The electronic absorption spectra of lanthanides-chlorophyll a compounds still had two absorption peaks, which were similar to the MgCA peaks. However, the absorption intensity changed a lot. For lanthanides mono-chlorophyll a compounds, the two peaks at the short- and long-wavelength bands, respectively, were lower than those of $\mathrm{MgCA}$, which demonstrated that the formation of lanthanides mono-chlorophyll a compounds reduced the absorbance of chlorophyll. For lanthanides bischlorophyll a compounds, at the short-wavelength band, both La and $\mathrm{Tb}$ enhanced the absorption intensity, whereas Ce weakened the absorption intensity, and at the long-wavelength band, all the compounds lowered the absorption intensity, except CALaCA2, CACeCA3, and CATbCA2.

The electronic absorption spectra of the most stable compounds for $\mathrm{La}, \mathrm{Ce}$, and $\mathrm{Tb}$ are depicted in Figure 6D. It was seen that the absorption intensity of MgCA was the largest, and the absorption intensity of TbCA1 was larger than that of LaCA2 and CeCA1.

\section{DISCUSSION}

In this study, we observed that treatments with REEs quickened the germination of alfalfa seeds, and the treatments with REEs at low concentration promoted the root growth of the seedling. The root is the main organ that absorbs water and nutrients. For the alfalfa seeds, the REEs treatments at appropriate concentration could enhance root activity. This phenomenon is consistent with the effect of REEs on root length reported by others (Diatloff et al., 1995). However, whether REEs are beneficial depends on the crop genotypes and the time of measurement (GarcíaJiménez et al., 2017).

In our experiments, $\mathrm{La}\left(\mathrm{NO}_{3}\right)_{3}(10$ and $20 \mu \mathrm{M}), \mathrm{Ce}\left(\mathrm{NO}_{3}\right)_{3}(10$ and $20 \mu \mathrm{M})$, and $\mathrm{Tb}\left(\mathrm{NO}_{3}\right)_{3}(10$ and $20 \mu \mathrm{M})$ were used to treat the alfalfa seeds, and distilled water was used as the control. So, the changes in physiological parameters were caused by both REEs and nitrate ions in our treatments with REEs. However, the response concentrations of plants to REEs and nitrate ions are different. Nitrate plays a role in nutrition and signaling in many plants, and it needs a relatively high concentration to stimulate or promote plant growth. For example, $\mathrm{KNO}_{3}$ concentrations from 1 to $25 \mathrm{mM}$ did not significantly affect the germination rate and speed of Senecio coincyi (Schnadelbach et al., 2016). Duermeyer et al. (2018) reported that the response concentration of various plants to nitrate was usually above $0.1 \mathrm{mM}$, which is much higher than that adopted in our experiments. In plants, the high-affinity nitrate transport system is used to absorb low concentrations of exogenous nitrogen. In alfalfa, the response concentration of exogenous nitrogen reported in the latest research was $5 \mathrm{mM}$ (Zou et al., 2019), and according to another study, the response concentration of exogenous nitrogen was $0.2 \mathrm{mM}$ in the soil (Wang et al., 2020). The response concentration of nitrate as exogenous nitrogen in alfalfa was reported at the $\mathrm{mM}$ level. According to the International Seed Testing Association (2017), even after 14 days of growing the seeds on paper, they did not lack nitrogen. Moreover, in our experiments, the seeds imbibed only $5 \mathrm{~mL}$ of REEs solution on the first day and were replenished with a specific quantity of water every day. The amount of nitrogen from an external source was extremely little. REEs usually have a positive impact on seed germination and growth at relatively low concentrations. For instance, Agathokleous et al. (2018) summarized the hormesis dose-response induced 

(1) $\mathrm{MgCA}+\mathrm{La}^{3+}$
$\mathrm{LaCA}^{+}+\mathrm{Mg}^{2+}$
$\Delta \mathrm{G}_{1}=280.6449 \mathrm{~kJ} \cdot \mathrm{mol}^{-1}$
(2) $\mathrm{MgCA}+\mathrm{La}^{3+}$
$\mathrm{LaCA}^{+}+\mathrm{Mg}^{2+}$
$\Delta \mathrm{G}_{2}=279.2062 \mathrm{~kJ} \cdot \mathrm{mol}^{-1}$
(3) $2 \mathrm{MgCA}+\mathrm{La}^{3+}$
$\mathrm{CALaCA1}^{-}+2 \mathrm{Mg}^{2+}$
$\Delta \mathrm{G}_{3}=693.1609 \mathrm{~kJ} \cdot \mathrm{mol}^{-1}$
(4) $2 \mathrm{MgCA}+\mathrm{La}^{3+}$
$\rightarrow \mathrm{CALaCA2}^{-}+2 \mathrm{Mg}^{2+}$
$\Delta \mathrm{G}_{4}=687.9361 \mathrm{~kJ} \cdot \mathrm{mol}^{-1}$
(5) $2 \mathrm{MgCA}+\mathrm{La}^{3+}$
$\rightarrow \mathrm{CALaCA}^{-}+2 \mathrm{Mg}^{2+}$
$\Delta \mathrm{G}_{5}=650.5779 \mathrm{~kJ} \cdot \mathrm{mol}^{-1}$
(6) $\mathrm{MgCA}+\mathrm{Ce}^{3+} \longrightarrow \mathrm{CeCA}^{+}+\mathrm{Mg}^{2+}$
$\Delta \mathrm{G}_{6}=196.2036 \mathrm{~kJ} \cdot \mathrm{mol}^{-1}$
(7) $\mathrm{MgCA}+\mathrm{Ce}^{3+}$
$\rightarrow \mathrm{CeCA}^{+}+\mathrm{Mg}^{2+}$
$\Delta \mathrm{G}_{7}=196.4137 \mathrm{~kJ} \cdot \mathrm{mol}^{-1}$
(8) $2 \mathrm{MgCA}+\mathrm{Ce}^{3+}$
$\mathrm{CACeCA} 1^{-}+2 \mathrm{Mg}^{2+}$
$\Delta \mathrm{G}_{8}=581.6717 \mathrm{~kJ} \cdot \mathrm{mol}^{-1}$
(9) $2 \mathrm{MgCA}+\mathrm{Ce}^{3+}$
$\mathrm{CACeCA2}^{-}+2 \mathrm{Mg}^{2+}$
(10) $2 \mathrm{MgCA}+\mathrm{Ce}^{3+}$
- $\mathrm{CACeCA3}^{-}+2 \mathrm{Mg}^{2+}$
$\Delta \mathrm{G}_{9}=573.6178 \mathrm{~kJ} \cdot \mathrm{mol}^{-1}$
(11) $\mathrm{MgCA}+\mathrm{Tb}^{3+}$
$\rightarrow \mathrm{TbCA}^{+}+\mathrm{Mg}^{2+}$
$\Delta \mathrm{G}_{10}=520.5697 \mathrm{~kJ} \cdot \mathrm{mol}^{-1}$
(12) $\mathrm{MgCA}+\mathrm{Tb}^{3+}$
$\rightarrow \mathrm{TbCA}^{+}+\mathrm{Mg}^{2+}$
$\Delta \mathrm{G}_{11}=145.8436 \mathrm{~kJ} \cdot \mathrm{mol}^{-1}$
(13) $2 \mathrm{MgCA}+\mathrm{Tb}^{3+}$
$\rightarrow \mathrm{CATbCA}^{-}+2 \mathrm{Mg}^{2+}$
$\Delta \mathrm{G}_{12}=153.7309 \mathrm{~kJ} \cdot \mathrm{mol}^{-1}$
(14) $2 \mathrm{MgCA}+\mathrm{Tb}^{3+}$
$\rightarrow \mathrm{CATbCA2}^{-}+2 \mathrm{Mg}^{2+}$
$\Delta \mathrm{G}_{13}=503.7495 \mathrm{~kJ} \cdot \mathrm{mol}^{-1}$
(15) $2 \mathrm{MgCA}+\mathrm{Tb}^{3+}$
$\rightarrow \mathrm{CATbCA3}^{-}+2 \mathrm{Mg}^{2+}$
$\Delta \mathrm{G}_{14}=466.5992 \mathrm{~kJ} \cdot \mathrm{mol}^{-1}$
$\Delta \mathrm{G}_{15}=435.9794 \mathrm{~kJ} \cdot \mathrm{mol}^{-1}$

FIGURE 5 | The changes in Gibbs free energy for the 15 possible reactions.

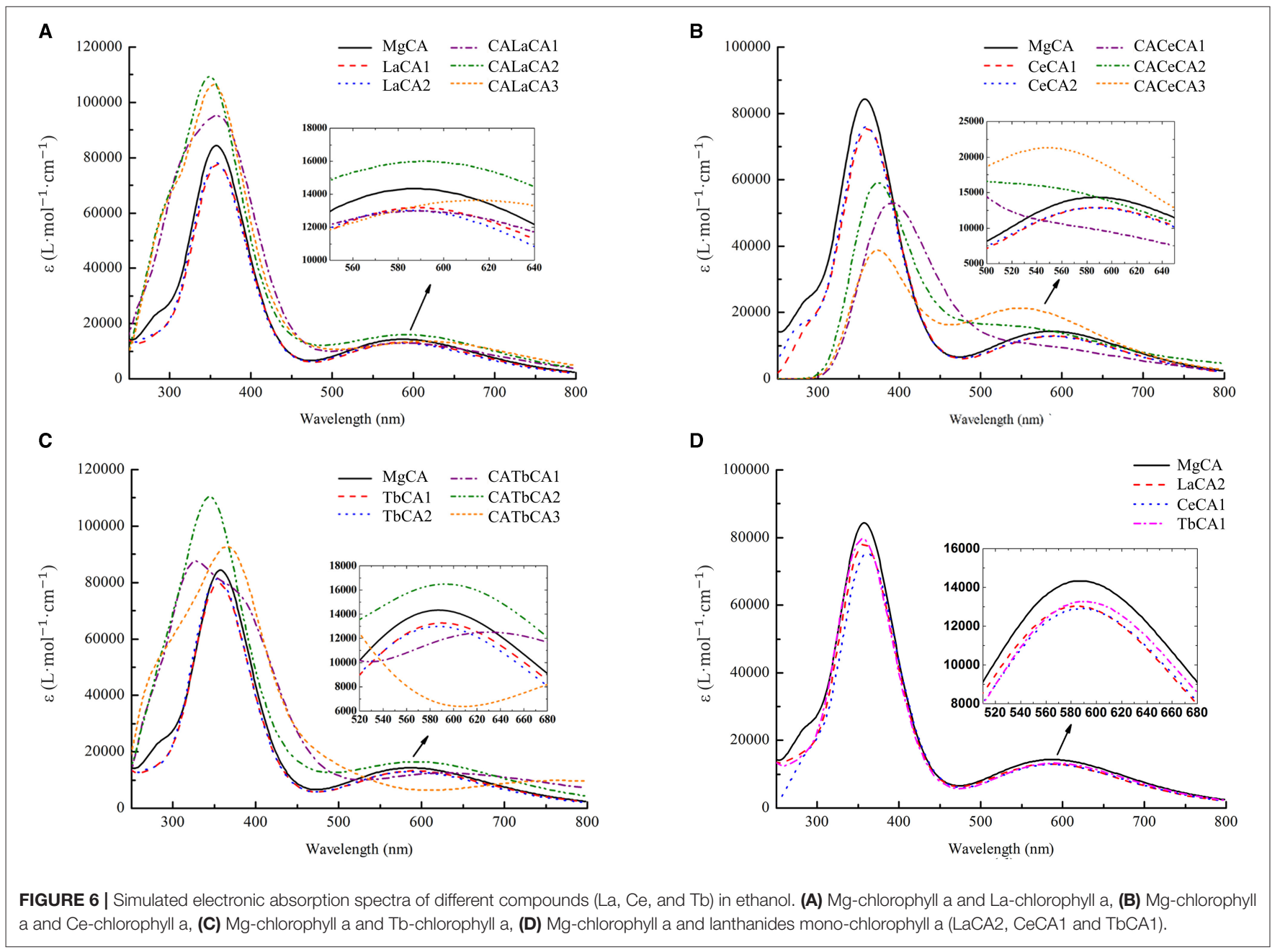


by lanthanum in plants and found that the "hormesis effect" commonly occurred at a concentration of few tens of $\mu \mathrm{M}$. So, the nitrate ion in our experiments may have a weak impact on alfalfa germination and growth. As a result, the REEs play a major role in alfalfa germination and growth based on our experiments.

The leaf chlorophyll content is an important index to reflect leaf physiological status. Wei et al. (2005) described that REEs are bound to chlorophyll and found that the REEs may replace magnesium in chlorophyll. Hong et al. (2002) studied the effect of Ce on chlorophyll of spinach and found that Ce could enter chloroplast and combine with chlorophyll. Our in vivo experiments also observed significant changes in the chlorophyll content in alfalfa leaves under different concentrations of REEs. However, there are two reasons for the change in chlorophyll content: (1) the change in total chlorophyll content; and (2) the change in chlorophyll structure. Therefore, we further carried out in vitro experiments and quantum chemical calculations.

The chlorophyll content was significantly decreased by REE treatments in vivo. This situation demonstrated that REEs might suppress chlorophyll production or change the chlorophyll form in alfalfa. This conclusion was evidenced in our in vitro experiments, which showed that $\mathrm{La}, \mathrm{Ce}$, and $\mathrm{Tb}$ treatments reduced the absorbance of chlorophyll by reacting with chlorophyll. Our quantum chemical calculations further predicted that $\mathrm{La}, \mathrm{Ce}$, and $\mathrm{Tb}$ could replace $\mathrm{Mg}$ in chlorophyll a, and form lanthanides mono-chlorophyll a and lanthanides bis-chlorophyll a compounds. The changes in Gibbs free energy for these substitution reactions revealed that lanthanides monochlorophyll a compounds were much easier to be formed than lanthanides bis-chlorophyll a compounds. The simulated electronic absorption spectra of lanthanides mono-chlorophyll a compounds showed that the replacements of $\mathrm{Mg}$ by $\mathrm{La}, \mathrm{Ce}$, and $\mathrm{Tb}$ lowered the absorption intensity of chlorophyll. So, we speculated that the formation of lanthanides-chlorophyll decreased the chlorophyll content in alfalfa. Our conclusion was consistent with the results of Hong et al. (2002), who found that lanthanum could replace magnesium ions to form spinach chlorophyll.

The chlorophyll content decreased in the order of $\mathrm{La}<$ $\mathrm{Ce}<\mathrm{Tb}$ in vivo. However, the absorbance decreased in the order of $\mathrm{La}>\mathrm{Ce}>\mathrm{Tb}$ in vitro. This contradiction was caused by the degree of difficulty in the substitution reactions. According to the change in Gibbs free energy, the possibility of replacing $\mathrm{Mg}$ by REEs followed in the order of $\mathrm{La}<\mathrm{Ce}<\mathrm{Tb}$. It was clear that although replacing $\mathrm{Mg}$ by $\mathrm{La}$ showed the maximum reduction in absorbance, $\mathrm{Tb}$ could replace the largest amount of $\mathrm{Mg}$. Therefore, more $\mathrm{Mg}$ could be replaced by $\mathrm{Tb}$ in the 14 days, and $\mathrm{Tb}$ treatment had the lowest absorbance and chlorophyll content in vivo.

It was reported that REEs may affect plant cells. Exogenous rare earth elements ( $\mathrm{La}, \mathrm{Ce}$, and $\mathrm{Tb}$ ) were immobilized on the plasma membrane by AGPs in the form of nanoparticles, and then irreversibly changed the molecules with the increase in concentration, thus damaging the cells (Wang et al., 2019). However, a low concentration of REEs only affected the normal photosynthesis of plants (Wang, L., et al., 2014). For example, most of the REEs with low concentration adhered to the cell wall (Ye et al., 2008) or bound to the cell membrane (Ouyang et al., 2003), and the free radical reaction was in equilibrium (Wang et al., 2009), which increased the stability of the membrane (Gill et al., 1981) and activity of the corresponding enzyme (Hu et al., 2016a), thus stimulating and compensating the chlorophyll content. On the other hand, a high concentration of REEs entered the cell and adhered to the chloroplast, changing the ultrastructure of the chloroplast (Hu et al., 2016b). Although LREEs and HREEs enter the cells in a similar way (Wang L. H. et al., 2014), they have different beneficial effects on different genotypes of plants under different culture conditions. García-Jiménez et al. (2017) found that on comparing with the control, chlorophyll content of pepper decreased after 15 days of hydroponics, but increased after 30 days of hydroponics. Kotelnikova et al. (2020) reported that there was no significant difference in decline in chlorophyll content, except for $\mathrm{La}(100 \mathrm{mg} / \mathrm{kg})$ group, when $\mathrm{La}, \mathrm{Ce}$, and $\mathrm{Nd}$ were applied to the soil. It means that different plants have different concentration dependence of REEs.

\section{CONCLUSIONS}

The results showed that treatments with REEs ( $\mathrm{La}, \mathrm{Ce}$, and $\mathrm{Tb}$ ) had an effect on the growth of alfalfa seedlings. Treatments with REEs quickened the germination of alfalfa seeds, and the treatments at appropriate concentrations promoted the growth of roots and increased root activity. Moreover, the chlorophyll content was significantly reduced under treatments with REEs, and its decrease was in the order of $\mathrm{La}>\mathrm{Ce}>\mathrm{Tb}$. Quantum chemical calculations predicted that $\mathrm{La}, \mathrm{Ce}$, and $\mathrm{Tb}$ could replace $\mathrm{Mg}$ in chlorophyll a, and form lanthanides mono-chlorophyll a and lanthanides bis-chlorophyll a compounds. The possibility of replacing $\mathrm{Mg}$ by REEs followed in the order of $\mathrm{La}<$ $\mathrm{Ce}<\mathrm{Tb}$. Therefore, in alfalfa, more Mg could be replaced by $\mathrm{Tb}$ in the 14 days, and the treatments with $\mathrm{Tb}$ had the lowest absorbance and chlorophyll content. Furthermore, REE fertilizers could result in the enrichment of rare earth elements in leaves.

\section{DATA AVAILABILITY STATEMENT}

The raw data supporting the conclusions of this article will be made available by the authors, without undue reservation.

\section{AUTHOR CONTRIBUTIONS}

$\mathrm{XH}$ : conceptualization, funding acquisition, supervision, and validation. KS, JG, SL, YS, HS, and BA: data curation and investigation. $\mathrm{XH}$ and $\mathrm{KS}$ : formal analysis, software, writingoriginal draft, and writing-review and editing. $\mathrm{XH}, \mathrm{KS}$, JG, SL, YS, HS, and BA: methodology. $\mathrm{TH}$ and $\mathrm{XH}$ : project administration and resources. All authors contributed to the article and approved the submitted version. 


\section{FUNDING}

This work was supported by the Tibet Finance Department Project (Grant No. XZ202001ZY0016N), the Key Industry Innovation Chain in Shaanxi Province of China (Grant No.

\section{REFERENCES}

Agathokleous, E., Kitao, M., and Calabrese, E. J. (2018). The rare earth element (REE) lanthanum (La) induces hormesis in plants. Environ. Pollut. 238, 1044-1047. doi: 10.1016/j.envpol.2018.02.068

Binnemans, K., Jones, P. T., Blanpain, B., Gerven, T. V., Yang, Y. X., Walton, A., et al. (2013). Recycling of rare earths-a critical review. J. Clean. Prod. 51, 1-22. doi: 10.1016/j.jclepro.2012.12.037

Chen, D. M., Liu, X., He, T. J., and Liu, F. C. (2003). Density functional theory investigation of chlorophyll diacid: electronic absorption spectrum and conformational inversion. Chem. Phys. 289, 397-407. doi: 10.1016/S0301-0104(03)00088-0

Chen, Z. H. (2001). Global rare earth resources and scenarios of future rare earth industry. J. Rare Earths 29, 1-6. doi: 10.1016/S1002-0721(10)60401-2

Chu, Z. X. (1994). Effect of $\mathrm{CeCl}_{3}$ on the photosynthetic characteristics of Spirulina Platensis. Rare Metals. 12, 212-217 (in Chinese).

Cotruvo, J. A. (2019). The chemistry of lanthanides in biology: recent discoveries, emerging principles, and technological applications. ACS Cent. Sci. 5, 1496-1506. doi: 10.1021/acscentsci.9b00642

Cynthia, D. O., Ramos, S. J., Siqueira, J. O., Valdemar, F., de Castro, E. M., Amaral Douglas, C., et al. (2015). Bioaccumulation and effects of lanthanum on growth and mitotic index in soybean plants. Ecotox. Environ. Safe. 122, 136-144. doi: 10.1016/j.ecoenv.2015.07.020

d'Aquino, L., Pinto, M. C., Nardi, L., Morgana, M., and Tommasi, F. (2009). Effect of some light rare earth elements on seed germination, seedling growth and antioxidant metabolism in Triticum durum. Chemosphere 75, 900-905. doi: 10.1016/j.chemosphere.2009.01.026

Diatloff, E., Smith, F. W., and Asher, C. J. (1995). Rare earth elements and plant growth: I. Effects of lanthanum and cerium on root elongation of corn and mungbean. J. Plant Nutr. 18, 1963-1976. doi: 10.1080/01904169509365037

Duermeyer, L., Khodapanahi, E., Yan, D., Krapp, A., Rothstein, S. J., and Nambara, E. (2018). Regulation of seed dormancy and germination by nitrate. Seed Sci. Res. 28, 150-157. doi: 10.1017/S096025851800020X

Ejazul, I., Yang, X., Li, T. Q., Liu, D., Jin, X. F., and Meng, F. H. (2007). Effect of $\mathrm{Pb}$ toxicity on root morphology, physiology and ultrastructure in the two ecotypes of Elsholtzia argyi. J. Hazard. Mater. 147, 806-816. doi: 10.1016/j.jhazmat.2007.01.117

Fevzi, E., Ceyda, O. K., Evren, Y., and Mustafa, K. (2020). Rare-earth element scandium improves stomatal regulation and enhances salt and drought stress tolerance by up-regulating antioxidant responses of Oryza sativa. Plant Physiol. Bioch. 152, 157-169. doi: 10.1016/j.plaphy.2020.04.040

Frisch, M. J., Trucks, G. W., Schlegel, H. B., Scuseria, G. E., Robb, M. A., Cheeseman, J. R., et al. (2010). Gaussian 09, Revision B.01. Wallingford, CT: Gaussian, Inc.

García-Jiménez, A., Gómez-Merino, F. C., Tejeda-Sartorius, O., and Trejo-Téllez, L. I. (2017). Lanthanum affects bell pepper seedling quality depending on the genotype and time of exposure by differentially modifying plant height, stem diameter and concentrations of chlorophylls, sugars, amino acids, and proteins. Front. Plant Sci. 8:308. doi: 10.3389/fpls.2017.00308

Gill, D. L., Grollman, E. F., and Kohn, L. D. (1981). Calcium transport mechanisms in membrane vesicles from guinea pig brain synaptosomes. J. Biol. Chem. 256, 184-192. doi: 10.1016/S0021-9258(19)70117-3

Guo, B. S. (1985). Present and future situation of rare earth research in Chinese agronomy, in New Frontiers in Rare Earth Science and Applications (Book), eds G. X. Xu and J. M. Xiao (Academic Press), 1522-6.

He, X. Q., You, P., and Sun, Y. F. (2020). Lanthanum and abscisic acid coregulate chlorophyll production of seedling in switchgrass. PLOS ONE 15:e0232750. doi: 10.1371/journal.pone.0232750
2019ZDLNY05-02), the National Natural Science Foundation of China (Grant No. 31502005), and the National College Students' Science and Technology Innovation Project (Grant No. S202010712001). The funders had no role in study design, data collection, and analysis.
Hong, F. S., Qu, C. X., and Wang, L. (2017). Cerium improves growth of maize seedlings via alleviating morphological structure and oxidative damages of leaf under different stresses. J. Agr. Food Chem. 65, 9022-9030. doi: $10.1021 /$ acs.jafc.7b03398

Hong, F. S., Wang, L., Meng, X. X., Wei, Z., and Zhao, G. W. (2002). The effect of cerium (III) on the chlorophyll formation in spinach. Biol. Trace Elem. Res. 89, 263-276. doi: 10.1385/BTER:89:3:263

Hong, F. S., Wei, Z. G., and Zhao, G. W. (2001). Extended X-ray absorption fine structure study of the bound form of Lanthanide in chlorophyllA from Dicranopterisdichotoma. Biol. Trace Elem. Res. 82, 289-295. doi: 10.1385/bter:82:1-3:239

Hu, H. Q., Wang, L. H., Li, Y. L., Sun, J. W., Zhou, Q., and Huang, X. H. (2016a). Insight into mechanism of lanthanum (III) induced damage to plant photosynthesis. Ecotox. Environ. Safe. 127, 43-50. doi: 10.1016/j.ecoenv.2016.01.008

Hu, H. Q., Wang, L. H., Zhou, Q., and Huang, X. H. (2016b). Combined effects of simulated acid rain and lanthanum chloride on chloroplast structure and functional elements in rice. Environ. Sci. Pollut. Res. 23, 8902-8916. doi: 10.1007/s11356-015-5962-9

Hu, Z. Y., Herfried, R., Gerd, S., and Ewald, S. (2004). Physiological and biochemical effects of rare earth elements on plants and their agricultural significance: a review. J. Plant Nutr. 27, 183-220. doi: 10.1081/PLN-120027555

International Seed Testing Association (2017). International Rules for Seed Testing. Bassersdorf: International Seed Testing Association.

Jie, H. G., and Yu, Z. H. (1985). Effects of REEs on increasing yield and physiology of wheat. J. Heilongjiang Agric. Sci. 1, 25-29 (in Chinese).

Kotelnikova, A., Fastovets, I., Rogova, O., and Volkov, D. S. (2020). $\mathrm{La}, \mathrm{Ce}$ and $\mathrm{Nd}$ in the soil-plant system in a vegetation experiment with barley (Hordeum vulgare L.). Ecotox. Environ. Safe. 206:111193. doi: 10.1016/j.ecoenv.2020.111193

Kovaríková, M., Tomášková, I., and Soudek, P. (2019). Rare earth elements in plants. Biol. Plant. 63, 20-32. doi: 10.32615/bp.2019.003

Krishna, B. B., Charles, P. W., and Veronica, A. M. (2020). Assessing the role of interseeding alfalfa into grass on improving pasture soil health in semi-arid Texas High Plains. Appl. Soil Ecol. 147:103399. doi: 10.1016/j.apsoil.2019.103399

Lian, H. D., Qin, C., Zhang, L., Zhang, C., Li, H. B., and Zhang, S. Q. (2018). Lanthanum nitrate improves phosphorus-use efficiency and tolerance to phosphorus-deficiency stress in Vigna angularis seedlings. Protoplasma 256, 383-392. doi: 10.1007/s00709-018-1304-3

Liang, T., Zhang, S., Wang, L., Kuang, H. T., Wang, Y., Hu, A., et al. (2005). Environmental biogeochemical behaviors of rare earth elements in soil-plant systems. Environ. Geochem. Health 27, 301-311. doi: 10.1007/s10653-004-5734-9

Liao, M. S., Watts, J. D., and Huang, M. J. (2006). DFT/TDDFT study of lanthanide mono- and bisporphyrin complexes. J. Phys. Chem. A 110, 13089-13098. doi: 10.1021/jp0632236

Liu, D. W., Wang, X., and Chen, Z. W. (2012). Effects of rare earth elements and REE-bingding proteins on physiological responses in plants. Protein Peptide Lett. 19, 198-202. doi: 10.2174/0929866127990 80121

Ma, Y., Kuang, L., He, X., Bai, W., Ding, Y., Zhang, Z., et al. (2010). Effects of rare earth oxide nanoparticles on root elongation of plants. Chemosphere 78 , 273-279. doi: 10.1016/j.chemosphere.2009.10.050

Nemykin, V. N., and Hadt, R. G. (2010). Interpretation of the UV-vis spectra of the meso (ferrocenyl)-containing porphyrins using a TDDFT approach: is gouterman's classic four-orbital model still in play? J. Phys. Chem. A 114, 12062-12066. doi: 10.1021/jp1083828 
Ochi, K., Tanaka, Y., and Tojo, S. (2014). Activating the expression of bacterial cryptic genes by rpoB mutations in RNA polymerase or by rare earth elements. J. Ind. Microbiol. Biot. 41, 403-414. doi: 10.1007/s10295-013-1349-4

Otlyotov, A. A., Ryzhov, I. V., Kuzmin, I. A., Zhabanov, Y. A., Mikhailov, M. S., and Stuzhin, P. A. (2020). DFT study of molecular and electronic structure of $\mathrm{Ca}$ (II) and $\mathrm{Zn}$ (II) complexes with porphyrazine and tetrakis (1,2,5-thiadiazole) porphyrazine. Int. J. Mol. Sci. 21:2923. doi: 10.3390/ijms21082923

Ouyang, J., Wang, X. D., Zhao, B., Yuan, X. F., and Wang, Y. C. (2003). Effects of rare earth elements on the growth of Cistanche deserticola cells and the production of phenylethanoid glycosides. J. Biotechnol. 102, 129-134. doi: 10.1016/S0168-1656(03)00019-1

Ramírez-Olvera, S. M., Trejo-Téllez, L. I., García-Morales, S., Pérez-Sato, J. A., and Gómez-Merino, F. C. (2018). Cerium enhances germination and shoot growth, and alters mineral nutrient concentration in rice. PLOS ONE 13:e194691. doi: 10.1371/journal.pone.0194691

Ritchie, R. J. (2006). Consistent sets of spectrophotometric chlorophyll equations for acetone, methanol and ethanol solvents. Photosynth. Res. 89, 27-41. doi: 10.1007/s111120-006-9065-9

Rowan, K. S. (1989). Photosynthetic Pigments of Algae, 1st Edn., English. Cambridge University Press.

Schnadelbach, A., Veiga-Barbosa, L., Martinez-Garcia, F., Jimenez-Valdes, A., and Perez-Garcia, F. (2016). Interpopulation germination response of Senecio coincyi (Asteraceae) cypselas to various nitrate $\left(\mathrm{KNO}_{3}\right)$ concentrations. Seed Sci. and Technol. 44, 1-7. doi: 10.15258/sst.2016.44.3.08

Shen, Z. Q., Kang, L., and Jin, C. Z. (1999). $\mathrm{Nd}^{3+}$ uptakes in cell of Euglena gracilis 277. Chin. Sci. Bull. 44, 1590-1596 (in Chinese).

Tommasi, F., Thomas, P. J., Pagano, G., Perono, G. A., Oral, R., Lyons, D. M., et al. (2020). Review of rare earth elements as fertilizers and feed additives: a knowledge gap analysis. Arch. Environ. Con. Toxicol. doi: 10.1007/s00244-020-00773-4. [Epub ahead of print].

Turra, C. (2018). Sustainability of rare earth elements chain: from production to food- a review. Int J. Environ. Heal. Res. 28, 23-42. doi: 10.1080/09603123.2017.1415307

Wang, L., Wang, W., Zhou, Q., and Huang, X. (2014). Combined effects of lanthanum (III) chloride and acid rain on photosynthetic parameters in rice. Chemosphere 112, 355-361. doi: 10.1016/j.chemosphere.2014.04.069

Wang, L. H., Cheng, M. Z., Yang, Q., Li, J. G., Wang, X., Zhou, Q., et al. (2019). Arabinogalactan protein-rare earth element complexes activate plant endocytosis. Proc. Natl. Acad. Sci. U.S.A. 116, 14349-14357. doi: 10.1073/pnas.1902532116

Wang, L. H., Li, J. G., Zhou, Q., Yang, G. M., Ding, X. L., Li, X. D., et al. (2014). Rare earth elements activate endocytosis in plant cells. Proc. Natl. Acad. Sci. U.S.A. 111, 12936-12941. doi: 10.1073/pnas.1413376111

Wang, L. H., Zhou, Q., and Huang, X. H. (2009). Photosynthetic responses to heavy metal terbium stress in horseradish leaves. Chemosphere 77, 1019-1025. doi: 10.1016/j.chemosphere.2009.07.065

Wang, Q., Huang, Y. G., Ren, Z. J., Zhang, X. X., Ren, J., Su, J. Q., et al. (2020). Transfer cells mediate nitrate uptake to control root nodule symbiosis. Nat. Plants 6, 800-808. doi: 10.1038/s41477-020-0683-6

Wei, Z., Hong, F., Ming, Y., Li, H. X., Feng, H., Zhao, G. W., et al. (2005). Subcellular and molecular localization of rare earth elements and structural characterizaion of yttrium bound chlorophyll a in naturally grown fern Dicranopteris dichotoma. Microchem. J. 80, 1-8. doi: 10.1016/j.microc.2004.07.005
Wen, K., Liang, C., Wang, L. H., Hu, G., and Zhou, Q. (2011). Combined effects of lanthanumion and acid rain on growth, photosynthesis and chloroplast ultrastructure in soybean seedlings. Chemosphere 84, 601-608. doi: 10.1016/j.chemosphere.2011.03.054

Xiong, B. K., Cheng, P., Guo, B. S., and Zheng, W. (2000). Rare Earth Element Research and Applications in Chinese Agriculture and Forest, 1st Edn., Chinese. Metallurgical Industry Press.

Xu, X., Zhu, W., Wang, Z., and Witkamp, G. J. (2003). Accumulation of rare earth elements in maize plants (Zea mays L.) after application of mixtures of rare earth element and lanthanum. Plant Soil 252, 267-277. doi: 10.1023/A:1024715523670

Yang, Q., Wang, L. H., He, J. F., Yang, Z. B., and Huang, H. (2018). Direct imaging of how lanthanides break the normal evolution of plants. J. Inorg. Biochem. 182, 158-169. doi: 10.1016/j.jinorgbio.2018.01.020

Yang, Q., Wang, L. H., Zhou, L., Yang, Z. B., Zhou, Q., and Huang, X. H. (2019). The glucosinolate regulation in plant: a new view on lanthanum stimulation the growth of plant. J. Rare Earths 37, 555-564. doi: 10.1016/j.jre.2018.08.015

Ye, Y. X., Wang, L. H., Huang, X. H., Lu, T. H., Ding, X. L., and Zhou, Q. (2008). Subcellular location of horseradish peroxidase in horseradish leaves treated with $\mathrm{La}(\mathrm{III}), \mathrm{Ce}(\mathrm{III})$ and $\mathrm{Tb}(\mathrm{III})$. Ecotox. Environ. Safe. 71, 677-684. doi: 10.1016/j.ecoenv.2007.11.020

Yin, Y. B. (2016). DFT study on deprotonation and protonation of porphyrins: how many protons can the porphyrin core take up? Comput. Theor. Chem. 1080, 38-46. doi: 10.1016/j.comptc.2016.01.022

Yuriy, A. Z., Igor, V. R., Iiya, A. K., Alexey, V. E., and Pavel, A. S. (2021). DFT study of molecular and electronic structure of Y, La and Lu complexes with porphyrazine and tetrakis(1,2,5-thiadiazole) porphyrazine. Molecules 26:113. doi: 10.3390/molecules 26010113

Ziegler, C. J., Erickson, N. R., Dahlby, M. R., and Nemykin, V. N. (2013). Magnetic circular dichroism spectroscopy of $\mathrm{N}$-confused porphyrin and its lionized forms. J. Phys. Chem. A 117, 11499-11508. doi: 10.1021/jp40 9013d

Zou, X., Liu, M. Y., Wu, W. H., and Wang, Y. (2019). Phosphorylation at Ser28 stabilizes the Arabidopsis nitrate transporter NRT2.1 in response to nitrate limitation. J. Integr. Plant Biol. 62, 865-876. doi: 10.1111/jipb.12858

Conflict of Interest: The authors declare that the research was conducted in the absence of any commercial or financial relationships that could be construed as a potential conflict of interest.

Publisher's Note: All claims expressed in this article are solely those of the authors and do not necessarily represent those of their affiliated organizations, or those of the publisher, the editors and the reviewers. Any product that may be evaluated in this article, or claim that may be made by its manufacturer, is not guaranteed or endorsed by the publisher.

Copyright (c) 2021 Song, Gao, Li, Sun, Sun, An, Hu and He. This is an open-access article distributed under the terms of the Creative Commons Attribution License (CC $B Y)$. The use, distribution or reproduction in other forums is permitted, provided the original author(s) and the copyright owner(s) are credited and that the original publication in this journal is cited, in accordance with accepted academic practice. No use, distribution or reproduction is permitted which does not comply with these terms. 